\title{
THE HISTORY OF THE IDEOLOGY OF COLLECTIVIZATION OF THE SOVIET GOVERNMENT IN 1920-1930
}

\author{
Noyibjon Maripjonovich Khudoyorov \\ Senior lecturer at the department of "History of Uzbekistan" of Andizhan State University, Andizhan region, \\ Republic of Uzbekistan
}

Article DOI: $\underline{\text { https://doi.org/10.36713/epra9530 }}$

DOI No: 10.36713/epra9530

\begin{abstract}
The article analyzes the collectivization policy of the Soviet government and its implementation, why the Bolsheviks decided to mass collectivize agriculture in the Union in the late 1920s, and how the mechanism for implementing this idea was developed, based on primary sources and scientific literature.

KEY WORDS: collectivization policy, socialist reconstruction, agriculture, local leaders, Soviet historiography, peasant communes, peasant farming, industrialization, statistics, manufacturing, poverty.
\end{abstract}

\section{INTRODUCTION}

The Soviet government's policy of collectivization in the 1920s and 1930s was described as "a decisive step in the path of socialist reconstruction". This was the essence of the establishment of a state monopoly on production, and the kolkhozes were a peculiar form of organization of agricultural labor, uniting individual farms. However, the first phase of the Soviet state's largest project to modernize the country through the collectivization of agriculture failed miserably. Private reasons were pointed out, such as the arbitrariness of local leaders, the rapid pace of collectivization, the low qualifications of the kolkhoz organizers, the conflicts in the countryside, and the growing mutual resentment. The historical fact that collectivization is a practice of violence against the peasant masses has been proven in the latest scientific research. One of the tragedies associated with collectivization and left an ominous mark on the lives of farmers was the labeling of entrepreneurs and business farmers as "kulaks". The tragedy of the "listened", unfortunately, did not end there. Their deportation from their homeland was another of these tragedies. This process has also left a deep, painful mark on the fate of hundreds of thousands of peasants who have been subjected to the violence, which has not been adequately covered as an important, integral part of the whole theme.

\section{RESEARCH METHODS}

The collectivization policy and practice of the Soviets was characterized by the Red Empire waging a violent war against the peasants. It is clearly based on indifference, haste and irregularities in the interests and mood of the peasants. In Soviet historiography, the idea of collectivization is interpreted as an integral part of Lenin's program of building a socialist society (industrialization, collectivization, and the cultural revolution). In particular, in his speech at the First All-Russian Congress of Land Departments, Committees of the Poor and Municipalities on September 11, 1918, he said, "... is something" [1].

\section{RESULTS AND DISCUSSIONS}

In his speech at the First Congress of Agricultural Commune and Agricultural Cooperatives on December 4, 1919, he said, Millions of small farms can be affected only by gradual, successful demonstrations" he said. In the years following the October coup, based on utopian theories, Bolshevik-courageously organized communes did not justify themselves in practice. This is because the first agricultural communes and artels were established on lands taken from former landowners and kulaks. They made their living only at the expense of the state, and were "poisoned by the peasants" because their production efficiency was so low.

In his speech at the VIII All-Russian Congress of Soviets on December 24, 1920, during the discussion of the draft law "On Measures to Strengthen and Develop Peasants' 


\title{
SJIF Impact Factor 2021: 8.013| ISI I.F.Value:1.241| Journal DOI: 10.36713/epra2016 \\ EPRA International Journal of Research and Development (IJRD)
}

\author{
Volume: 7 | Issue: 2 | February 2022
}

- Peer Reviewed Journal

Agriculture" Lenin said [3]. The Russian scholar V.M. Samosudov argues that Lenin never prioritized collectivization among the various forms of cooperation [4]. The New Economic Policy (hereinafter NEP), which began in 1921, had certain results in the early kulaks of socialist construction. Political stability has emerged during the NEP era. The political monopoly of the Bolsheviks was strengthened, its prestige grew and its influence on the people increased. This is explained by the relative decline of counter-revolutionary speeches during this period. Under NEP conditions, certain changes have taken place in the lives of farmers. Although the living conditions of the poor, who owned a small amount of land, did not improve quickly, he was able to work relatively freely and independently. Because during this period the Bolsheviks were less involved in the economic affairs of the peasants, and the role of the village Soviets was less high. As a result of the gradual normalization of rural life, the Soviet government managed to gain the attention of a large part of the rural population. The position and influence of the Bolsheviks was growing, especially among the rural youth. However, these changes have failed to address two pressing issues on the agenda. The first is the backwardness of farms, low production capacity (lack of equipment, labor organization, etc.), and the second is the deterioration of urban life due to the migration of farmers and the acceleration of urbanization. This situation had a negative impact on the Bolshevik industrialization plan and market relations between urban and rural areas and dealt a serious blow to the foundations of the NEP. With the strengthening of the administrative-command system after the death of Lenin, the ideas of the NEP were abandoned in the late 1920s. In the process of debating the theoretical foundations of socialist state-building and industrialization and collectivization in the second half of the 1920s, an opposition emerged that did not approve of the ideological path chosen by the Central Committee, headed by Stalin, and promoted other ways and means. It was divided into two directions: the "left" led by L. Trotsky, Preobrazhensky and Pyatakov, and the "right" led by N. Bukharin, Rikov and Tomsky. The opposition has put forward its own alternative program of collectivization and opposition to the peasants, especially the "attitude to the kulaks". While the "left" advocated drastic measures against the kulaks, relying only on the poor peasants, the "right" advocated not to take emergency measures against the peasants, arguing that "the kulaks grow into socialism through cooperation". The opposition tried to prove theoretically that their ideas were acceptable. Initially, from the summer of 1927, pressure, repression against the "left" intensified. Despite the fact that the VKP (b) X Congress banned the faction within the party, "leftists" staged demonstrations, secretly published brochures, and engaged in other illegal activities. As a result, Trotsky and Zinovev were expelled from the party on November 15, 1927. The 15th Congress decided to expel all members of the "leftist opposition" from the party. A few weeks later, Trotsky and his fierce supporters were expelled from the capital. The 15 th Congress of the VKP (b) (December 2-19, 1927) went down in history as the
"Congress for the Collectivization of Agriculture and the Preparation for the Onslaught of Socialism on the Whole Front". Collectivization was to allow the state to obtain a large proportion of agricultural products at low prices in the interests of industrialization. At the congress, Stalin insisted that the only way to solve the problems of Soviet agriculture was to work the land collectively. The resolution on Molotov's report "On Rural Work" set the party's main task in the countryside as uniting small individual farms into large collectives.

The congress did not set the pace and timing of collectivization. There was no talk of mass collectivization. On the contrary, any pressure and administrative measures against the peasants were condemned [6]. The resolution emphatically stated that this could be done only if the peasants agreed to such a transition, and found it necessary to widely propagate that the gradual transition to large-scale social agriculture was necessary and beneficial for farmers, and to encourage large-scale collective farming elements in practice. At the request of the directives and circulars signed by Stalin and Molotov, it was announced that "party organizations have been set up" and that "all the work of party organizations will be evaluated in terms of the collectivization of farms". The amount of state aid to the collective farms has increased dramatically. However, there was no clear idea of the form of the kolkhoz. Speaking at the First All-Union Congress of Collective Farmers of the Soviet Union on June 1, 1928, the "All-Union Elder" M.I. Kalinin was forced to admit that he "could not find the best form of collective farm that would unite production in the countryside". Although Stalin's proposals were not reflected in the decisions of the Plenum, in the policy of the Central Committee of the CPSU (b) these principles began to be fully implemented. All the rural communists were among the first to enter the kolkhozes under the pressure of disciplinary action. The kolkhoz center gained additional powers in the structure of the kolkhoz. Rural cooperatives undertook to supply machinery, machines and tractors only to the collective farms. The mobilization also spread to trade unions and Komsomol organizations. They set out to carry out party policy in the village on behalf of party activists and GPU staff. In the resolution of the Plenum of the Central Committee of the CPSU (b) of November 16-24, 1928 "On control numbers of the national economy in 1928-1929", the main task of the party was to The first shift will be made in the "gradual consolidation of scattered peasant farms into large consolidated farms" [10].

Mass collectivization was primarily a means of raising the funds needed by the Soviet state to implement the country's industrialization program. The Bolsheviks could supply the resources of the countryside to the city precisely through the kolkhozes. The kolkhozes played an important role in the party's obtaining additional products from the peasants for industry. Of course, this is an important factor, but not the main one. Stalin's victory in the struggle for power of the party's "geniuses" is also cited as one of the reasons for the transition to a policy of mass collectivization. During the grain crisis of 1928, the "right" led by N.I. Bukharin, A.I. 


\title{
SJIF Impact Factor 2021: 8.013| ISI I.F.Value:1.241| Journal DOI: 10.36713/epra2016 \\ EPRA International Journal of Research and Development (IJRD)
}

\author{
Volume: 7 | Issue: 2 | February 2022
}

- Peer Reviewed Journal

Rikov promoted an alternative program. They advocated not imposing emergency measures on farmers, but rather strengthening economic measures. However, those in the "right opposition" have made a serious mistake in their political activities. Bukharin held secret talks with opposition leader L. Kamenev. The publication of the conversation in a secret Troika newspaper undermined the opposition's image among party members. Stalin skillfully used this event.

Stalin based his theory on the "intensification of the class struggle" in the struggle against the opposition. Both the ideological and organizational suppression of the opposition allowed Stalin to use methods of violence against the peasants from November 1929 through a policy of mass collectivization and the abolition of the kulaks as a class. The ideas and conclusions of Stalin in his article "The Year of the Great Turn", published in the newspaper "Pravda" on November 7, 1929, on the collectivization of agriculture, were an expression of far-reaching goals. The article pointed out that the decisive victory of the Soviet state was when the peasants turned to the kolkhozes. "Now the peasants do not enter the collective farms individually, but with the whole village, the whole district, even the whole district. What does this mean? This means that middle-class peasants are now entering the collective farms. This is the essence of this turning point in the development of agriculture, which formed the success of the Soviet government in recent kulaks" [13] wrote I. Stalin. Real life shows the opposite. The reason was that at that time not only the middle class but also the poor peasants were forced to join the kolkhoz. As a result of the top-down demolition of rural NEP foundations, it was no longer possible for individual farms to survive as independent small commodity producers. The foundations of agricultural cooperation were severely damaged during the "emergency measures". As a result of the strong administrative-repressive pressure and propaganda of the Soviet government, some of the poor who were losing their livelihoods had no choice but to join the kolkhoz.

As of October 1, 1929, only $7.6 \%$ of all farms in the Union [14] and no more than 3.4\% in Uzbekistan [15] belonged to collective farms. Given that the poor make up $35 \%$ of all farms in the USSR [16] and $43 \%$ in Uzbekistan [17], collective farms cover a quarter of the poor in the Union and less than a tenth in Uzbekistan. The resolution of the Plenum of the Central Committee of the CPSU (b) of November 1929 "On the results and future tasks of the construction of the collective farm" noted the facts mentioned in Stalin's article announced the start.

In the plenum, the issue of the pace of collectivization was considered a key issue. Speaking on November 15 on G.N. Kaminsky's report, V.M. Molotov said he had high hopes for the 1930 sowing campaign, noting that "we have 4.5 months left - November, December, January, February, March" [18], noting that mass collectivization will take place in the spring. However, to the issue of sending 25,000 "politically mature" workers to the countryside, Molotov said, "We must approach this measure as an urgent, high-level measure". The November Plenum also considered it necessary to establish the USSR People's Commissariat of Land Affairs in order to centralize the management of agricultural work. On December 7, 1929, the resolution of the Central Executive Committee of the USSR Soviets "On the Establishment of the People's Commissariat of Land Affairs of the USSR" was published. Ya.A.Yakovlev was appointed People's Commissar for Land Affairs. This commissariat played a key role in the development of plans for mass collectivization and the implementation of the measures of the VKP (b) against the peasants. At the meeting of the Politburo of the Central Committee of the CPSU (b) on December 5-7, 1929. A special commission headed by Yakovlev was set up. The special commission worked in two directions: on the rate of collectivization (chairman G.N. Kaminsky); on the treatment of the kulaks (Chairman K.Ya. Bauman)

The available factual evidence suggests that the process of drafting resolutions on these issues was uncompromising, that there were differing views on the mechanisms, pace and timing of collectivization, but that very short deadlines were set as a result of Stalin's and Molotov's pressure. On December 27, 1929, familiar with the draft resolution on collectivization, Stalin delivered a speech at the Conference of Agrarian Marxists "On Agrarian Policy in the USSR". Emphasizing the kolkhoz movement as the most important event in socio-economic life, he focused on theoretical issues. In this speech, for the first time, he officially announced the transition from a policy of limiting the exploitative tendencies of the kulaks to a policy of ending their existence as a class. However, two years ago, collectivization should be carried out gradually, for which economic, financial, cultural, political measures, large sums of money were needed. By December 1929, Stalin dared to say that the material base for collectivization was ready.

\section{CONCLUSION}

The conclusion is that the theory and practice of collectivization, which emerged during the years of Soviet rule, has been abandoned to this day. Great attention is paid to the transfer of land to its rightful owner, the farming movement of farming. This is because the construction of a collective farm based on social animosity and violence, without taking into account the interests, aspirations and aspirations, worldviews and psychology of certain social strata, did not justify itself in practice.

\section{REFERENCES}

1. Aminova R. Collectivization means impoverishment // "Shark yulduzi”" (Star of the East). -Tashkent, 1992. №12.p. 183.

2. Lenin V.I. About the peasant union with the working class. T: Uzdavnashr, 1955. - 563 p.

3. Resolutions and decisions of congresses, conferences and plenums of the Central Committee of the CPSU. T.3.924 1927. T., "Uzbekistan" 1983. 455 p.

4. Lenin V.I. Collection of complete works, volume 42, T: Uzbekistan, 1979. - 213 p. 


\section{EPRA International Journal of Research and Development (IJRD)}

5. Samosudov V.M. Modern domestic historiography of collectivization (1980s - mid-90s years). - Omsk, 1998. - 15 p.

6. Stephen Cohen. Bukharin. Political biography. 1888-1938. M.: Progress, 1988. - 328 p.

7. Documents testify. From the history of the village on the eve and during the collectivization of 1927-1932.

8. Resolutions and decisions of congresses, conferences and plenums of the Central Committee of the CPSU. T. IV. 1927 - 1931. -T: Uzbekistan, 1983, - 57 p.

9. Danilov V.P. Collectivization of agriculture in the USSR. In the book "Collectivization of agriculture in the republics of Central Asia and Kazakhstan: experience and problems" Alma-Ata: Gylim, 1990. - 47 p.

10. Resolutions and decisions of congresses, conferences and plenums of the Central Committee of the CPSU. T.4. 1924 1927. - T: Uzbekistan, 1983. -131-136 p

11. Shamsutdinov R.T. Soviet policy of kulak in Uzbekistan and its tragic consequences. - T: Shark, 2001. - 227 p.

12. Boffa D. History of the Soviet Union. - M.: International relations, $1990 .-310 \mathrm{p}$.

13. Stalin I.V. A year of great turning points. Latin graphics. (Translation of the Prophet). - Samarkand Baku: Uzdavnashr, 1930. - $21 \mathrm{p}$.

14. Ivnitsky N.A. The fate of the dispossessed in the USSR. M.: Collection, 2004. - 11 p.

15. Aminova R.Kh. Returning to the history of collectivization in Uzbekistan. - T: Fan, 1995. - P.19.

16. Ivnitsky N.A. The fate of the dispossessed in the USSR. M.: Collection, 2004. - P. 11.

17. Changing the class structure of society in Uzbekistan during the years of Soviet power (1917-1980), - T: Fan, 1984. - P. 130.

18. Resolutions and decisions of congresses, conferences and plenums of the Central Committee of the CPSU. T. IV. 1927 - 1931. - T: Uzbekistan, 1983. - 378-380 p.

19. The tragedy of the Soviet village. Collectivization and dispossession. 1927-1929 Documents and materials. T.1. May 1927 - November 1929. - M: ROSSPEN, 1999. - 759 $p$.

20. Resolutions and decisions of congresses, conferences and plenums of the Central Committee of the CPSU. T. IV. 1927 - 1931. - T: Uzbekistan, 1983. - 392 p.

21. The tragedy of the Soviet village. Collectivization and dispossession. 1927-1929 Documents and materials. T.2. November 1929 - December 1930. - M: ROSSPEN, 2000. p. 3-11.

22. Stalin I.V. Works, T.12, April 1929 - June 1930. - T: Uzdavnashr, 1950. - 157-191 p. 